\title{
Sorption and mobility of dimethenamid in a volcanic soil amended with liquid cow manure
}

\author{
O. Candia ${ }^{1}$, R. Demanet ${ }^{1}$, T. Fernández ${ }^{1}$, M. L.Mora ${ }^{1}$, G. Briceño ${ }^{1}$, G. Palma $^{1 *}$ \\ ${ }^{1}$ Bioresource Nucleus, Universidad de La Frontera, Temuco, Chile. ${ }^{*}$ Corresponding author: \\ graciela.palma@ufrontera.cl
}

\begin{abstract}
This work studied the sorption and mobility of dimethenamid (2-chloro-N-(2,4-dimethyl-3-thienyl)-N-(2methoxy-1-methylethyl)-acetamide) in soil amended with liquid cow manure (LCM) at doses equivalent to 0 , 100, 200 and 300 thousand $\mathrm{L} \mathrm{ha}^{-1}$ (D0, D100, D200 and D300 respectively). For the batch sorption study the amended soils were previously incubated for 30 days under controlled conditions. The mobility was evaluated under field conditions, determining the herbicide retained in different soil profiles and its concentration in soil solutions sampled with ceramic suction cups. Application of LCM at the two lowest doses (D100 and D200) did not modify dimethenamid adsorption, however adsorption increased at D300 $\left(\mathrm{K}_{\mathrm{foc}}=62.1\right)$ as compared with D0 $\left(\mathrm{K}_{\mathrm{foc}}=42.3\right)$. This result could be explained by the higher content of dissolved organic matter in D300, since the addition of LCM does not change the organic matter content in the soil. The results of the field trials showed that D300 adsorbed the highest amount of dimethenamid in the upper layer of soil, and that the amount of dimethenamid in leachates was lower than that of D0. The results showed that high doses of amendment contribute to higher herbicide retention in the topsoil, reducing leaching.
\end{abstract}

Keywords: Herbicide, manure, amendment, leaching, sorption

\section{Introduction}

The south of Chile contains a high level of livestock farming, principally for milk production. The manure produced by dairy cattle, which is a mixture of cattle urine, feces and wash water, is accumulated in slurry pits. In winter the pits are emptied and the manure is used to irrigate the soil on which the farmers plant forage corn. The amounts of LCM applied vary, sometimes reaching excessive amounts of up to $300,000 \mathrm{Lha}^{-1}$. Unlike other manures, LCM is mostly liquid, with a low organic matter (OM) content and high amounts of dissolved organic matter (DOM), P, N, minerals and water (Briceño et al., 2008). As such its application 
to volcanic soils, rich in organic matter, is considered to be a fertilization amendment (Briceño et al., 2008). The farming practices for corn management, after the application of LCM, also include application of atrazine and dimethenamid as pre-plant herbicides, in doses of 1.5 liters per hectare each; however, farmers have observed inefficient weed control.

A significant number of works have been conducted to assess the effect of applying animal amendments to soils (Balemi, 2012; Dolaptsoglou et al., 2007; Malik et al., 2013). They mainly investigate soils with a low OM content, in which the high OM content of the amendment results in an increase in adsorption capacity and consequently a reduction in leaching (Moorman et al., 2001; Albarrán et al., 2004; Wanner et al., 2005; Farenhorst et al., 2006; Si et al., 2006; López-Piñeiro, et al., 2010). Moreover, the application of animal amendments also greatly increases the amount of DOM in the soil, modifying the herbicide adsorption process and consequently the volume of leaching. Both increases and decreases of pesticide leaching have been observed (Singh, 2003, Jiang et al., 2008, Song et al., 2008; Dal Bosco et al., 2013). A decrease in pesticide adsorption may occur either by DOM-pesticide complexation or by DOM competition with pesticide molecules for soil adsorption sites (Said-Pullicino et al., 2004). The opposite effect, i.e. higher pesticide adsorption, can be also observed as a result of DOM adsorption onto soil which then provides additional adsorption sites for pesticides (Singh, 2003; Briceño et al., 2007; Majumdar and Singh, 2007). The effect of both insoluble and soluble $\mathrm{OM}$ on pesticide adsorption is not easy to predict, especially when liquid amendment with high DOM is applied. There is therefore a need to study the optimum dose for the application of amendments and the effects of animal manure application on pesticide mobility. Soil amendments may increase/decrease pesticide mobility, playing a significant role in managing the risk of water source contamination.

Dimethenamid is a herbicide of the chloroacetamide group used mainly in preemergence to control grass in corn, soybean and many other crops. Dimethenamid and its degradation products are potentially highly toxic for many organisms, including humans (Hladik et al., 2008). Dimethenamid is highly soluble in water $\left(1,389 \mathrm{mg} \mathrm{L}^{-1}\right)$, and can be moderately adsorbed by soil with a $\mathrm{K}_{\mathrm{oc}}$ ranging from 40 to $200 \mathrm{~L} \mathrm{~kg}^{-1}$, with a half-life $\left(\mathrm{t}_{1 / 2}\right)$ of up to 6 weeks (Crawford et al., 2002; FOOTPRINT database, 2012). Occurrence of dimethenamid in drinking water have been reported by Hladik et al., (2008), but lysimeter studies carried out under field conditions did not show presence of residual dimethenamid (EFSA, 2005). Studies carried out by Archangelo et al. (2004) showed that dimethenamid adsorption is highly dependent on soil OM content, with a weak interaction and no $\mathrm{pH}$ dependence.

The aim of this work was to assess, under controlled and field conditions, the influence of LCM dose on dimethenamid adsorption and mobility in a volcanic soil.

\section{Materials and Methods}

The soil used was an Andisol from southern Chile of the Vilcún series (Pachic Melanudands), with a silty loam texture (197 $\mathrm{g}_{\text {sand }} \mathrm{kg}^{-1}, 467 \mathrm{~g}$ silt $\mathrm{kg}^{-1}, 336 \mathrm{~g}$ clay $\left.\mathrm{kg}^{-1}\right)$. Precipitation is around 2,000 mm per year ${ }^{-1}$ and the average temperature $15^{\circ} \mathrm{C}$. For laboratory experiments, soil samples 
were collected from the topsoil layer to a depth of $20 \mathrm{~cm}$, air-dried and sieved through a 2-mm mesh. The soil had no prior application of LCM and dimethenamid. The LCM was collected from an open slurry pit located near the dairy plant. Dimethenamid (99\% purity) was supplied by Chem Service. In the field assay, commercial EC-dimethenamid was applied (Frontier EC, $900 \mathrm{~g} \mathrm{~L}^{-1}$ a.i., BASF, Chile).

\subsection{Chemical analysis of LCM and soil}

The LCM was analyzed according to the methodology of Peters et al. (2003). Briefly, the $\mathrm{pH}$ and electrical conductivity (EC) were measured in non-diluted LCM. Dry matter (DM) content was determined by water evaporation at $70{ }^{\circ} \mathrm{C}$. Total nitrogen was determined by the Kjeldal method. $\mathrm{P}$ and $\mathrm{K}$ were analyzed in ash obtained by dry matter incineration at $550{ }^{\circ} \mathrm{C}$, using colorimetry and emission spectrophotometry respectively. The OM content was estimated by mass difference between the LCM and ash. To estimate the DOM, the LCM was centrifuged and the supernatant filtered through a $0.45 \mathrm{~mm}$ membrane (Millipore), lyophilized, and analyzed as total organic carbon (TOC) (EURO EA 3000 Elemental Analyzer). The main characteristics of the LCM were: $\mathrm{pH}$ 7.5, EC $5.9 \mathrm{dS} \mathrm{m} \mathrm{m}^{-1} \mathrm{DM} 53.0 \mathrm{~g} \mathrm{~L}^{-1}$ of LCM N 28.6, P 6.8, K 18.0, OM $0.742 \mathrm{~g} \mathrm{~kg}^{-1}$ of DM, and TOC $2140 \mathrm{mg} \mathrm{L}^{-1}$ of LCM.

The soil sample was characterized based on methods described by Sadzawkaet al. (2006) (Table 1). Briefly, the $\mathrm{pH}$ was measured by potentiometry in a soil-water suspension. The EC (1:5) was measured by conductivity in water soil extract. The OM was determined by wet digestion using the Walkley-Black procedure.

\subsection{Incubation and Characterization of LCM-amended soils}

The soil was placed in polyethylene bags and LCM was added at doses equivalent to $0,100,000$, 200,000 and 300,000 Lha $^{-1}$ (D0, D100, D200 and D300 respectively). Volumes of $0,70,140$ and $200 \mathrm{~mL}$ of LCM per $\mathrm{kg}$ of soil respectively were added and mixed vigorously, assuming that LCM is incorporated in the top $20 \mathrm{~cm}$ of soil, and a soil density of $0.75 \mathrm{~g} \mathrm{~mL}^{-1}$. The soil moisture content was set at $70 \%$ of field capacity, and adjusted periodically during the experiment by adding distilled water. The LCM-amended soils were incubated in aerobic conditions, in the dark at $20{ }^{\circ} \mathrm{C}$ for 30 days. LCM-amended soils were characterized according to the method described above for soil (Sadzawka et al. 2006) (Table1). The DOM was extracted from the soils with distilled water, at a soil:water ratio of $1: 10(\mathrm{v}: \mathrm{v})$, by shaking for 24 hours at $20^{\circ} \mathrm{C}$. The suspensions were centrifuged at $2000 \mathrm{rpm}$ and filtered, and DOM was analyzed as described above. The analysis included total acidity, determined by the $\mathrm{Ba}(\mathrm{OH})_{2}$ method, carboxyl group content by the $\mathrm{Ca}\left(\mathrm{CH}_{3} \mathrm{COO}\right)_{2}$ method, and the phenolic hydroxyl group content was calculated by the difference (Perdue, 1985). The E4/E6 ratio was determined as the ratio of absorbance at 440 and $640 \mathrm{~nm}$ in solutions of $2 \mathrm{mg}$ of DOM in $10 \mathrm{~mL}$ of $0.1 \mathrm{M} \mathrm{KOH}$ using a UV/Vis spectrophotometer (Mora et al., 1995).

\subsection{Dimethenamid adsorption isotherms}

In batch experiments, the equilibrium kinetics of dimethenamid adsorption were obtained by placing $3.5 \mathrm{~g}$ of sample from each treatment 
(D0, D100, D200 and D300) and $7 \mathrm{~mL}$ of a dimethenamid solution prepared in $\mathrm{CaCl}_{2}$ $0.01 \mathrm{M}$ into a $25 \mathrm{~mL}$ centrifuge tube, with an initial concentration $\left(\mathrm{C}_{\mathrm{i}}\right)$ of $1.5 \mathrm{mg} \mathrm{\textrm {L } ^ { - 1 }}$. The suspensions were shaken continuously in a reciprocating shaker in darkness at $20^{\circ} \mathrm{C}$. The tubes were removed at 1, 2, 4, 12, 24, 48 and 72 hours. The samples were centrifuged for $20 \mathrm{~min}$ at $2000 \mathrm{rpm}$, filtered through $0.45 \mu \mathrm{m}$ membranes (Millipore) and analyzed by HPLC. The adsorption experiment was carried out by preparing solutions of dimethenamid dissolved in $\mathrm{CaCl}_{2} 0.01 \mathrm{M}$ with an initial concentration $\left(\mathrm{C}_{\mathrm{i}}\right)$ ranging between 0.05 and $4.00 \mathrm{mg} \mathrm{L}^{-1}$. Samples of $3.5 \mathrm{~g}$ of each soil and $7.0 \mathrm{~mL}$ of dimethenamid solution were placed in $25 \mathrm{~mL}$ centrifuge tubes and shaken in darkness at $20^{\circ} \mathrm{C}$ for $24 \mathrm{~h}$. The suspensions were centrifuged for $20 \mathrm{~min}$ at 2000 rpm and filtered through $0.45 \mu \mathrm{m}$ membranes (Millipore). The equilibrium concentration of dimethenamid $\left(\mathrm{C}_{\mathrm{e}}\right)$ was determined by HPLC and differences between $\mathrm{C}_{\mathrm{i}}$ and $\mathrm{C}_{\mathrm{e}}$ were assumed to correspond to dimethenamid adsorbed by the soils. The adsorption isotherms were explained according to the logarithmic expression of the Freundlich equation: $\log \mathrm{C}_{\mathrm{s}}=\log \mathrm{K}_{\mathrm{f}}+(1 / \mathrm{n})$ $\log \mathrm{C}_{\mathrm{e}}$ where $\mathrm{C}_{\mathrm{s}}\left(\mathrm{mg} \mathrm{kg}{ }^{-1}\right)$ is the herbicide adsorbed on the soil, $\mathrm{C}_{\mathrm{e}}\left(\mathrm{mg} \mathrm{L}^{-1}\right)$ is the aqueous herbicide concentration at equilibrium, $\mathrm{K}_{\mathrm{f}}$ is the Freundlich adsorption coefficient $\left(\mathrm{mg}^{(1-1 / \mathrm{n})} \mathrm{L}^{1 / \mathrm{n}} \mathrm{kg}\right.$ $\left.{ }^{1}\right)$ and $\left(1 / n_{f}\right)$ is the Freundlich exponent. The $K_{f}$, normalized to the organic carbon content of the soils $\left(\mathrm{K}_{\mathrm{foc}}\right)$, was also calculated. A control tube with herbicide solution was used to discard any degradation of the herbicide during the study. The experiments were conducted in triplicate. The dimethenamid adsorptions studies were carried out with amended soils 30 days after application of the amendment.

\subsection{Herbicide analysis}

The dimethenamid concentration was determined on a Merck Hitachi 3400, HPLC instrument (Merck Analytical Instrument Co.) equipped with an UV variable wavelength detector set at $220 \mathrm{~nm}$. A volume of $20 \mu \mathrm{L}$ of filtered solution was injected into a Symmetry C18 column $(250 \times 4.6 \mathrm{~mm}$, i.d. $5 \mu \mathrm{m})$ and the mobile phase consisted of a 45:55 (v:v) mixture of water and acetonitrile (Crawford et al., 2002).

\subsection{Field experiment}

The field experiment was located in General Lopez $\left(38^{\circ} 41^{\prime} \mathrm{S}, 72^{\circ} 22^{\prime} \mathrm{W}\right)$ in the Araucanía region. The soil (Andisol) and LCM were the same used for the adsorption experiments (Table 1). The experimental design consisted of four plots $35 \times 15 \mathrm{~m}$, separated by a distance of $5 \mathrm{~m}$, used for the unamended soil (D0) and LCM-amended soils (D100, D200 and D300) treatments. Each plot contained sub-plots of $5 \times 3 \mathrm{~m}$ with four replications, separated by $1.5 \mathrm{~m}$ each. The experiments were established in a randomized complete block design. The LCM was applied 30 days before herbicide application and the commercial dimethenamid formulation was applied at $1.5 \mathrm{~L} \mathrm{ha}^{-1}$ the day after the maize was sown, in October of 2012. To collect soil solutions, three ceramic suction cups of $6 \mathrm{~cm}$ length, $2 \mathrm{~cm}$ i.d. were installed in each sub-plot at $60 \mathrm{~cm}$ depth according to Sánchez et al., (2006). The water samples were taken over two months. The leachates were filtered and lyophilised, then reconstituted in 1 $\mathrm{mL}$ of methanol and filtered through $0.22 \mu \mathrm{m}$ membranes (Millipore), for subsequent analysis by HPLC. The soil in each plot was sampled 
at $0-15,15-30,30-45$ and $45-60 \mathrm{~cm}$ depth, 5, 10,20 and 30 days after herbicide application, with an auger $2 \mathrm{~cm} \times 1 \mathrm{~m}$. Dimethenamid was extracted using a modification of the method proposed by Anderson et al. (2005): $50 \mathrm{~g}$ of each soil sample was extracted with $50 \mathrm{~mL}$ of a mixture of methanol-water 95:5 (v:v) and shaken for $1 \mathrm{~h}$ at $20^{\circ} \mathrm{C}$, followed by $30 \mathrm{~min}$ in an ultrasonic bath. The supernatant was collected, and this procedure was repeated three times. The combined supernatant extracts were centrifuged at $2000 \mathrm{rpm}$ and filtered through $0.45-\mu \mathrm{m}$ membranes (Millipore). The liquid extract was concentrated to $5 \mathrm{~mL}$ at $40^{\circ} \mathrm{C}$ in a rotary evaporator (Heidolph WV 2000) and they were liquid-liquid extracted with $10 \mathrm{~mL}$ of hexane in a separating funnel; this process was repeated 3 times. The hexane extract was dried in a rotary evaporator, and the sample was dissolved in $2 \mathrm{~mL}$ of methanol. The solution was filtered through a $0.22-\mu \mathrm{m}$ filter, and the residual herbicide was measured by HPLC.

\subsection{Data analysis}

The data were subjected to statistical analyses of variance (ANOVA), and all mean separations were determined using Tukey's test $(p \leq 0.05)$.

\section{Results and Discussion}

\subsection{Physico-chemical characterization of LCM and amended soils}

LCM is high in $\mathrm{P}$ and $\mathrm{N}$, with low dry matter content, low OM and high DOM compared with other cattle-manure amendments (Briceño et al., 2007). Because of these last two characteristics, LCM is regarded as a fertilizer amendment, and does not contribute to increasing the organic matter of an Andisol. Table 1 shows the characterization of soil (D0) and LCM-amended soils (D100, D200 and D300) at 1 day and 30 days after application of the amendment. The high DOM content provided by the application of LCM amendment to the soil, compared with unamended soil, is noteworthy even one month after application. At the beginning the DOM determined as TOC in the amended soils were 6 to 11 times greater than in the unamended soil. After day $30 \mathrm{D}$ the TOC decreased, but it was still higher than the unamended soil in a ratio of about $1: 2$. The decrease could be due to DOM mineralization processes and adsorption on soils (Briceño et al., 2008).

Table 1. Characterization of soil and LCM-amended soils.

\begin{tabular}{llllllll}
\hline Property & \multicolumn{3}{c}{ Day 1 } & \multicolumn{5}{c}{ Day 30 } \\
\cline { 2 - 8 } & D0 & D100 & D200 & D300 & D100 & D200 & D300 \\
\hline pH & 5.3 & 5.5 & 5.7 & 6.1 & 5.3 & 5.2 & 5.7 \\
OM $(\%)$ & 19 & 17 & 19 & 17 & 17 & 18 & 16 \\
$\mathrm{P}\left(\mathrm{mg} \mathrm{kg} \mathrm{k}^{-1}\right)$ & 27 & 28 & 29 & 29 & 28 & 29 & 29 \\
$\mathrm{~K}\left(\mathrm{mg} \mathrm{kg}^{-1}\right)$ & 188 & 391 & 430 & 782 & 520 & 559 & 798 \\
$\mathrm{TOC}\left(\mathrm{mg} \mathrm{kg}^{-1}\right)$ & 51 & 280 & 390 & 533 & 75 & 93 & 131 \\
$\mathrm{EC} 1: 5\left(\mu \mathrm{Sm}^{-1}\right)$ & 217 & 360 & 574 & 680 & 330 & 493 & 542 \\
$\mathrm{C} / \mathrm{N} \mathrm{ratio}$ & 16.5 & 16.1 & 15.3 & 13.3 & 15.8 & 16.2 & 16.3 \\
\hline
\end{tabular}

LCM was applied on soil at doses equivalent to $0,100,000,200,000$ and 300,000 $\mathrm{L} \mathrm{ha}^{-1}$ (D0, D100, D200, and D300, respectively). DOM was analyzed as total organic carbon (TOC). 
Under field conditions, the time elapsed between the last application of the amendment and the application of herbicide is one month. This time was determined in our research group as the time necessary for LCM-amended soils to stabilize, evaluated by microbiological assessment under controlled conditions (Aguilera et al., 2009, Candia et al., 2012).

The characterization of DOM and water extract of D0, D100, D200 and D300, 30 days after amended application (Table 2), showed no major differences between D0 and LCM-amended soils amended application (Table 2), showed no major differences between D0 and LCM-amended soils in these parameters. LCM-DOM presented less phenolic acidity, higher carboxylic acidity and lower total acidity than water extract from soils. For the E4/E6 ratio no major differences were found, although this ratio increased slightly for DOM of the highest dose (D300).

Table 2. Characterization of DOM from LCM, soil(D0) and LCM-amended soils (D100, D200, D300).

\begin{tabular}{lcccc}
\hline Sample & Total acidity & Carboxylic acidity & Phenolicacidity & E4/E6 ratio \\
& $\left(\mathrm{meq} \mathrm{g}^{-1}\right)$ & $\left(\mathrm{meq} \mathrm{COOH} \mathrm{g}^{-1}\right)$ & $\left(\mathrm{meq}_{\text {phenol OH g }}{ }^{-1}\right)$ & \\
\hline D0 & 6.7 & 1.2 & 5.4 & 1.2 \\
D100 & 6.8 & 0.9 & 5.9 & 1.2 \\
D200 & 6.9 & 1.2 & 5.8 & 1.2 \\
D300 & 6.8 & 0.9 & 6.0 & 1.4 \\
LCM & 5.7 & 2.3 & 3.4 & 1.5 \\
\hline
\end{tabular}

LCM was applied on soil at doses equivalent to $0,100,000,200,000$ and 300,000 $\mathrm{L} \mathrm{ha}^{-1}$ (D0, D100, D200, and D300, respectively).

According to Plaza et al. (2003), the E4/E6 ratio is negatively correlated with particle size, molecular weight and $\mathrm{C}$ content. Otherwise, DOM is found to be more aliphatic and has less condensation than fulvic acids from Andisols (Mora and Canales, 1995; Rivero et al., 2004). An FTIR study carried out previously by our research group showed that LCM affects the chemical properties of the amended soils according to the origin and application rate of the amendment. In general, FTIR suggests an increase in aliphaticity, presence of $\mathrm{N}$-containing groups and polysaccharide-like groups (Briceño et al., 2008).

\subsection{Adsorption of dimethenamid on amended soils}

The adsorption kinetic of dimethenamid showed that equilibrium time was reached in about $14 \mathrm{~h}$ 
for all soils, although $24 \mathrm{~h}$ was used in further studies in order to ensure equilibrium conditions. Table 3 shows the Freundlich parameters $\left(\mathrm{K}_{\mathrm{f}}, 1 / \mathrm{n}\right)$ for dimethenamidad soption. The Freundlich adsorption model fitted very well for dimethenamid in these amended soils, with $\mathrm{R}^{2}$ values of $0.97 . \mathrm{K}_{\mathrm{f}}$ for D0; D100 and D200 presented no significant differences, with $\mathrm{K}_{\mathrm{f}}$ values ranging from 4.82 to 5.08 , while a significant difference was observed for D300, with $\mathrm{K}_{\mathrm{f}}$ of 5.78. Archangelo et al. (2004) reported $\mathrm{K}_{\mathrm{f}}$ values for dimethenamid ranging from 0.61 to 6.87 in soils with increasing OM content. In D300, the higher DOM of $131 \mathrm{mgkg}^{-1}$ (Table 1) may result in the increased adsorption. The increase of herbicide adsorption due to additional organic matter from the amendment has been reported previously (Singh, 2003), but the effect of DOM on herbicide adsorption is complex and several aspects need to be considered. Barriuso et al. (1992) studied the influence of water soluble organic matter from different sources and in general concluded that adsorption of the less soluble herbicides was favored in soils pre-treated with DOM and decreased for more soluble herbicides, although the response depends on the origin of the DOM. Moreover, decreased sorption and enhanced transport of hydrophobic substances by DOM have been observed for organic compounds with octanol-water partition coefficient $\left(\mathrm{K}_{\text {ow }}\right)$ greater than $10^{5}$ (Huang and Lee, 2001). This was not expected for dimethenamid, since it is a relatively hydrophilic compound with water solubility of $1,389 \mathrm{mg} \mathrm{L}^{-1}$ and $\mathrm{K}_{\text {ow }}$ near $10^{2}$.

Table 3. Parameters of the Freundlich equation $\left(\mathrm{K}_{\mathrm{f}}\right.$ and $\left.1 / \mathrm{n}\right), \mathrm{K}_{\mathrm{foc}}$ and $\mathrm{OC}$ values for dimethenamid in soil (D0) and LCM-amended soils (D100, D200, D300).

\begin{tabular}{lcccrc}
\hline Soil & $\mathrm{K}_{\mathrm{f}}$ & $1 / \mathrm{n}$ & $\mathrm{R}^{2}$ & $\mathrm{OC}$ & $\mathrm{K}_{\text {foc }}$ \\
& & & & & \\
& $\mathrm{mg}{ }^{(1-(1 / \mathrm{n}))} \mathrm{L}^{(1 / \mathrm{n})} \mathrm{kg}^{-1}$ & & & $\%$ & $\mathrm{mg}{ }^{(1-(1 / \mathrm{n}))} \mathrm{L}^{(1 / \mathrm{n})} \mathrm{kg}^{-1}$ \\
\hline D0 & $4.86 \mathrm{~b}$ & 0.76 & 0.97 & 11.5 & 42.3 \\
D100 & $4.82 \mathrm{~b}$ & 0.72 & 0.97 & 9.9 & 48.7 \\
D200 & $5.08 \mathrm{~b}$ & 0.73 & 0.97 & 10.5 & 48.3 \\
D300 & $5.78 \mathrm{a}$ & 0.71 & 0.97 & 9.3 & 62.1 \\
\hline
\end{tabular}

LCM was applied on soil at doses equivalent to $0,100,000,200,000$ and 300,000 $\mathrm{L} \mathrm{ha}^{-1}$ (D0, D100, D200, and D300, respectively). Different letters indicate significantly different values in the same row $(p \leq 0.05)$.

OM-rich Andisol offers many sorption sites for both dimethenamid and DOM. Herbicide sorption may be enhanced if the DOM sorbed on soils provides additional sites for herbicide sorption and additional sorption of DOMherbicide complex from the soil solution (Dal Bosco et al., 2008). Dimethenamid may interact with soil and DOM by different mechanisms 
such as transfer charge, van der Waals, and hydrogen bonds (Archangelo et al., 2004).

\subsection{Field results}

In order to evaluate the mobility of dimethenamid, a field trial was conducted using the same LCM doses as in laboratory conditions (D100, D200, and D300). As mentioned previously, the LCM amendment was applied 30 days before dimethenamid, because this time was estimated as necessary for the amended soils to stabilize. Table 4 shows the amounts of herbicide measured in leachates by field lysimeters (60 $\mathrm{cm}$ depth) in soil (D0) and cow slurry-amended soils (D100,
D200 and D300) over approximately two months after dimethenamid application. Sampling of the soil solution presented several difficulties, such as low volumes collected and no solutions on some sampling dates, but it was clearly established that dimethenamid leaches more easily in D0 and D100 than D200 and D300. Dimethenamid has been reported to be a poorly leachable herbicide (Archangelo et al., 2004), which agrees with our results. According to $\mathrm{Si}$ et al. (2006), a reduction in soil infiltration due to an increase in total solids from the amendments applied could explain why there is less leaching at a higher application dose. After 40 days it was not possible to collect soil solution.

Table 4. Dimethenamid ( $\mu \mathrm{g})$ in leachates using ceramic suction cups placed at $60 \mathrm{~cm}$ depth from D0, D100, D200 and D300.

\begin{tabular}{lllll}
\hline Time (days) & D0 & D100 & D200 & D300 \\
\hline 20 & $5.5 \pm 1.0$ & $4.0 \pm 0.6$ & $3.0 \pm 1.2$ & $2.0 \pm 0.6$ \\
28 & $5.0 \pm 1.5$ & $6.5 \pm 1.8$ & $4.5 \pm 1.2$ & $3.0 \pm 0.9$ \\
40 & $5.5 \pm 0.8$ & $5.0 \pm 0.6$ & $1.5 \pm 0.5$ & $1.5 \pm 0.5$ \\
Total & $16.0 \mathrm{a}$ & $15.5 \mathrm{a}$ & $9.0 \mathrm{~b}$ & $6.5 \mathrm{~b}$ \\
\hline
\end{tabular}

LCM was applied on soil at doses equivalent to 0, 100,000, 200,000 and 300,000 $\mathrm{L} \mathrm{ha}^{-1}$ (D0, D100, D200, and D300, respectively). Different letters show significant differences between treatments for total leachate collections $(p \leq 0.05)$.

Figure 1 shows the residual dimethenamid for D0, D100, D200 and D300 in soil profiles. Five days after dimethenamid application it ranged between $53-75 \%$ of the applied dimethenamid with a trend $\mathrm{D} 0<\mathrm{D} 100<\mathrm{D} 200<\mathrm{D} 300$, but no significant differences were found except for D300 compared to D0. The D300 soil adsorbed the highest amount of dimethenamid in the upper soil layer, compared with the other treatments, showing a dose effect of the amendement. After 10 days, the dimethenamid concentration is very low for all profiles, and no significant differences were observed between treatments. 

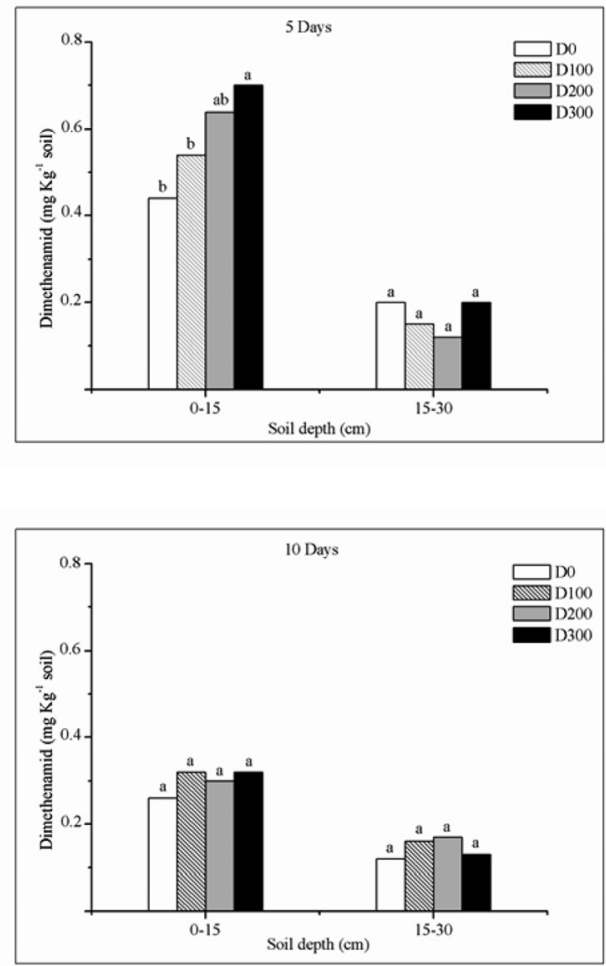

Figure. 1. Residual dimethenamid concentration $\left(\mathrm{mg} \mathrm{kg}^{-1}\right)$ in soil (D0) and LCM-amended soils (D100, D200 and D300) in field conditions sampling at 5 and 10 days. Different letters show significant differences between treatments at the same sampling time and depth $(p \leq 0.05)$.

A first order kinetic model for the $0-15$ soil profile (Nkedi-Kizza and Brown, 1998) was used to estimate the half-life $\left(t_{1 / 2}\right)$ of dimethenamid under field conditions. No significant differences were found between the treatments and the $\mathrm{t}_{1 / 2}$ was about 5 days. A previous laboratory experiment reported by us (Candia et al., 2012) showed a $t_{1 / 2}$ value of 26 days. The difference between $t_{1 / 2}$ values under field and laboratory conditions was expected due to herbicide leaching losses and weather conditions that accelerate the degradation of the herbicide in the field. According to Crawford et al. (2002), in a field study that monitored the dissipation of several chloroacetamides in the $0-8 \mathrm{~cm}$ fraction of the soil surface, the time observed for the disappearance of $50 \%$ of applied dimethenamid ranged from 4-11 days.

\section{Conclusions}

The application of LCM to OM-rich Andisol did not increase the soil OM, however it increased DOM considerably. For the highest dose, an increase in dimethenamid adsorption was found in amended soil. The mobility of dimethenamid 
in field condition confirms this result, with a lower concentration of leachates.

\section{Acknowledgments}

This research was financed by FONDECYT, project 1070568

\section{References}

Aguilera, P., Briceño, G., Candia, M., Mora, M.L.,Demanet, R., Palma, G. 2009. Effect of dairy manure rate and the stabilization time of amended soils on atrazine degradation. Chemosphere. 77, 785-790.

Albarrán, A., Celis, R.,Hermosín, M.,LópezPiñeiro, A., Cornejo, J. 2004. Behaviour of simazine in soil amended with the final residue of the olive-oil extraction process. Chemosphere. 54, 717-724.

Anderson, K., Basile, J., Johnson, E. 2005. Analytical method for dimethenamid-P in selected raw agricultural commodities by gas chromatography with electron capture detection. J. AOAC Int. 88,1428-1432.

Archangelo, E., Karam,D., Ferreira, F., Prates, H., Ferreira, L., Cardoso, A. 2004. Sorption, desorption, and leaching potential of dimethenamid in Brazilian soils. Planta Daninha. 22,467-477.

Balemi, T. 2012. Effect of integrated use of cattle manure and inorganic fertilizers on tuber yield of potato in Ethiopia. J. Soil Sci. Plant Nut. 12, 253-261.

Barriuso, E., Baer, U., Calvet, R. 1992. Dissolved organic matter and adsorption-desorption of dimefuron, atrazine and carbetamide by soils. J. Environ. Qual. 21, 359-367.
Briceño, G., Palma, G., Durán, N. 2007. Influence of organic amendment on the biodegradation and movement of pesticides. Crit. Rev. Environ. Sci. and Technol. 37, 233-271.

Briceño, G., Demanet, R., Mora, M.L., Palma, G.2008. Effect of liquid cow manure on Andisol properties and atrazine adsorption. J. Environ. Qual. 37, 1519-1526.

Briceño, G., Jorquera, M.,Demanet,R., Mora, M.L., Durán, N., Palma, G. 2010. Effect of cow amendment on atrazine dissipation and bacterial community structure in an agricultural Andisol. Sci. Total Environ. 408, 2833-2839.

Candia, O., Mora, M.L., Demanet, R., Briceño, G., Palma, G. 2012. Effect of liquid cow manure amendment on dimethenamid persistence in a volcanic soil. J. Soil Sci. Plant Nutr. 12,153-163.

Crawford, J., Sims, G.,Simmons, F., Wax, L., Freedman, D. 2002. Dissipation of the herbicide $\left[{ }^{14} \mathrm{C}\right]$ dimethenamid under anaerobic conditions in flooded soil microcosms. J. Agric. Food Chem. 50, 14831491.

Dal Bosco,T., Sampaio, S., Machad,S., Correa, M., Netto, A., Jersak, N. 2013. The influence of organic matter from swine wastewater on the interaction and transport of alachlor in soil. Acta Sci. Agron. 35, 277-286.

Dolaptsoglou, C., Karpouzas, D.,MenkissogluSpiroudi, U., Eleftherohorinos, I.,Voudrias, A. 2007. Influence of different organic amendments on the degradation, metabolism, and adsorption of terbuthylazine. J. Environ. Qual. 36, 1793-1802. 
EFSA Scientific Report. 2005. Conclusion regarding the peer review of the pesticide risk assessment of the active substance dimethenamid.

Farenhorst, A., Reimer, M., Londry, K.,Saiyed, I. 2006. 2, 4-Dichlorophenoxy acetic acid mineralization in amended soil. J. Environ. Sci. Health B. 41,509-522.

Fernández-Bayo, J., Nogales, R., Romero, E. 2008. Evaluation of the sorption process for imidacloprid and diuron in eight soils from southern Europe using various kinetic models. J. Agric. Food Chem. 56, 52665272.

FOOTPRINT DATABASE. Available at http:// sitem.herts.ac.uk/aeru/footprint/

Hladik, M., Bouwer, E., Roberts, A. 2008. Neutral chloroacetamide herbicide degradates and related compounds in Midwestern United States drinking water sources. Sci. Total Environ. 390,155-165.

Huang, X., Lee, L. 2001. Effect of Dissolved organic matter from animal waste effluent on chlorpyrifos sorption soils. J. Environ. Qual. 30, 1258-1265.

Jiang, L.,Huang, J., Liang, L., Zheng, P., Yang, H. 2008. Mobility of prometryne in soil as affected bydissolved organic matter. J. Agric. Food Chem. 56,11933-11940.

López-Piñeiro, A., Cabrera, D., Albarrán, A., Peña, D. 2010. Cumulative and residual effects of de-oiled two-phase olive mill waste application to soil on diuron sorption, leaching, degradation, and persistence. Chemosphere 78, 139-146.

Majumdar, K., Singh, N. 2007. Effect of soil amendments on sorption and mobility of metribuzin in soils. Chemosphere. 66, 630-637.
Malik, M. A., Khan, K. S., Marschner, P., Fayyaz-ul-Hassan. 2013. Microbial biomass, nutrient availability and nutrient uptake by wheat in two soils with organic amendments. J. Soil Sci. Plant Nut. 13, 955-966.

Moorman, T.,Cowan, J.,Arthur, E., Coats, J. 2001. Organic amendments to enhance herbicide biodegradation in contaminated soils. Biol. Fertil. Soils. 33, 541-545.

Mora, M.L., Canales, J. 1995. Interactions of humic substances with allophanic compounds. Commun. Soil Sci. Plant Anal. 26, 2805-2817.

Nkedi-Kizza, P., Brown, K. 1998.Sorption, degradation and mineralization of carbaryl in soils for single pesticide and multiple pesticide systems. J. Environ. Qual. 27, 1318-1324.

Perdue, E., 1985.Acidic functional groups of humic substances. In: Aiken, G.R., McKnight, D.M., Wershaw, R.L., MacCarthy, P. (Eds.), Humic substances in soil, sediment and water. Geochemistry, isolation, and characterization. Wiley/Interscience, New York, pp. 493-536.

Peters, J., Combs, S., Hoskins, B.,Jarman, J.,Kovar, J., Watson, M., Wolf, A., Wolf, N. 2003. Recommended methods of manure analysis (A3769). Univ. of Wisconsin, Madison.

Plaza, C., Senesi, N., Polo, A., Brunetti, G., Garcia-Gil, J., D’Orazio, V. 2003. Soil fulvic acid properties as a means to assess the use of pig amendment. Soil Till. Res. 74, 179-190.

Rivero, C., Chirenje, T., Ma, L., Martinez, G. 2004.Influence of compost on soil organic matter quality under tropical conditions. Geoderma. 123, 355-361. 
Sadzawka, A., Grez,R., Carrasco, M.,Mora, M.L. 2006. Método de análisis recomendados para los suelos Chilenos. Comisión de Normalización y Acreditación Sociedad Chilena de la Ciencia del suelo, Santiago.

Said-Pullicino, D., Gigliotti, G. and A. Vella., 2004. Environmental fate of triasulfuron in soils amended with municipal waste compost. J. Environ. Qual. 33: 1743-1751.

Sánchez, L., E. Romero, A. Castillo, and A. Peña. 2006. Field study of methidathion in soil amended with biosolid and a cationic surfactant under different irrigation regimes. Solute transport modeling. Chemosphere 63: 616-625.
Si, Y., J. Zhang, S. Wang, L. Zhang, and D. Zhou. 2006. Influence of organic amendment on the adsorption and leaching of ethametsulfuronmethyl in acidic soil in China. Geoderma. 130: 66-76.

Singh, N. 2003. Organic manure and urea effect on metalochlor transport through packed soil columns. J. Environ. Qual. 32: 1743-1749.

Song, N.H., L. Chen, and H. Yang. 2008. Effect of dissolved organic matter on mobility and activation of chlorotoluron in soil and wheat. Geoderma 146: 344-352.

Wanner, U., F. Fuhr, and P. Burauel. 2005. Influence of the amendment of corn straw on the degradation behavior of the fungicide dithianon in soil. Environ. Pollut. 133: 63-70. 